specimen and its state of preservation, pointing out sources of error arising from confounding superinduced structures in the rock, with original markings on the organism. He compared it with those species which appear most nearly to resemble it among previously described forms. He pointed out the exact geological horizon from which it was obtained, as determined by the associated fossils, and then gave the technical description of his new species.

The same treatment of the specimens and of the species is seen in his description " of "Two Abnormal Cretaceous Echinoids."

In Palæontology also we must look for his work not so much in published descriptions of new species, as in the large numbers of named fossils in the Woodwardian Museum, from almost every horizon, the determination of which we owe to him.

The characteristic of his work as of the man was its honesty. We who lived and worked with him up to a few days of the end feel his loss at once; he is no longer there to help, and many another coming up to the old Museum from time to time will feel it too; for when a friend or stranger asked to see something in our collections, we would say, "You will find Tom Roberts there," with full confidence that our visitor would return well pleased and the honour of our Museum would be well sustained.

He was a man of great force of character, of clearness of vision, and soundness of judgment. False reasoning rarely escaped him, and you could no more lose sight of his intellectual presence than of his large and powerful frame. Yet his gentle sympathetic manner and his open truthful eye gave you at once the comfortable feeling that you need not be on your guard with him. Students said that he never tried to put himself on a higher pedestal by scoring off them. He led them on, and rather than drive or urge them, he would ask them to help him to get them through with credit, as if he, not they, were most interested in their success.

T. McKenny Huares.

\title{
FREDERICK DREW, F.G.S., F.R.G.S.
}

Borx Acgust 11, 1836. Dikd October 25, 1891.

Mr. Frederick Drew, F.G.S., F.R.G.S., was born August 11th, 1836, at Southampton, where his father kept a well-known private school, and at this school he was educated until he was seventeen years of age, when he entered the Royal School of Mines, at that time (1853) recently established in connexion with the Jermyn Street Museum. Here he distinguished himself, although younger than some of the other students, by taking all the prizes offered, including the Duke of Cornwall's Scholarship, a Royal Scholarship, and the Edward Forbes medal, the last two for the first year in which they were awarded.

In 1855, on leaving the School of Mines, Frederick Drew joined the Geological Survey of Great Britain, and remained on the staff till 1862, being chiefly engaged in the south-east of England. His

1 Grol. Mas. Vol. VIII. 1891, p. 116. 
principal contributions to science during these seven years included an important paper on the Hastings Sands, published in the Quart. Journ. Geol. Soc. for 1861, and an account of the Geology of Folkestone, Rye, and Romney Marsh, which appeared in the Geological Survey Memoirs. The subdivisions of the Hastings Sands proposed by Drew have been accepted by the Survey and by British geologists generally, and he introduced some modifications of much value in the classification of the Lower Cretaceous beds throughout the Wealden area.

In 1862 the Maharaja of Kashmir desired to have the services of a geologist to report on the mining wealth of his country, and the appointment was accepted by Drew, who remained for ten years in Kashmir. At first he was, nominally, engaged in mining research ; naturally the ideas of an Indian Maharaja and those of a European geologist as to the methods and objects of such inquiries wonld differ materially, and it is not only highly creditable to Drew, but rather remarkable that, despite the inherent difficulties of his position, he should have impressed the Maharaja and his advisers so favourably as to be appointed first to the governorship of Jummu, and subsequently to the still more important one of Ladák. There can be no question that his skill and tact in dealing with natives of India, and his even temper and coolness in emergency, led to his being entrusted with the important posts that he filled.

The principal results of his residence in Kashmir, and of the exceptional opportunities he enjoyed for seeing the country and its inhabitants, were communicated to the public in his well-known work on Jummu and Kashmir, published in 1875. ${ }^{1}$ The greater part of his geological observations were necessarily reported to the Kashmir Goverument alone, but some purely scientific notes on the alluvial deposits that occupy so enormous an area in the Upper Indus Basin, as in other parts of Central Asia, were communicated by him to the Geological Society. ${ }^{2}$ A large portion of this paper is an account of the physical geography of the country, and describes the land contours and their mode of origin in Ladák and other parts of Kashmir territory, whilst the work on Jummu and Kashmir is a storehouse of geographical and ethnological data, of which later writers have frequently had occasion to avail themselves. The work is well written and extremely interesting. An abridged edition was published by the author in 1877 , under the title of "Northern Barrier of India."

The only communication to the publications of the Royal Geographical Society that appeared from Drew's pen was bis description, in a letter to Sir Roderick Murchison, of the steps taken, under instructions from the Maharaja of Kashmir, to ascertain the circumstances attending the murder of Mr. Hayward, the well-known explorer of the countries lying north of Kashmir. Mr. Hayward,

1 The Jummo and Kashmir Territories, a Geographical Account. By Frederick Drew, F.G.S., F.R.G.S., Assoc.R.S.M. London, 1875.8 8o. pp. xvi. and 568. 8 folding maps and sections, and 34 illustrations.

2 Quart. Journ. Geol. Soc. vol. xxix. 1873, pp. 411-471. 
who was a medallist of the Royal Gcographical Society, was killed when on his road to the Pamir, by Mir Wali of Yassin, chiefly, it appears, for the sake of plunder. The whole of the circumstances were ascertained by Drew, and an unfounded suspicion that at one time existed against the Kashmir Government was dispelled.

After returning to England in somewhat enfeebled health in 1872, Drew was for some timie unemployed, and he devoted his leisure to the preparation of his book on Jummu and Kashmir, upon which his reputation for the future must mainly depend. In 1875 he accepted a mastership at Eton, and remained in the college until his death. The duties of his post required constant attendance, and for the last few years he has been but rarely able to take part in the meetings of any of the London scientific societies. He was, however, too widely known, and too generally esteemed by his old friends of the School of Mines, the. Geological Survey of Great Britain, the Geological Society, and the Royal Geographical Society, as well as by those who knew him in Kashmir, to be forgotten, and it is a matter for deep regret that his untimely death has prevented his taking that position amongst scientific men in London for which his talents, his knowledge, his tact, and pleasing manners preeminently qualified him. ${ }^{1}$

Mr. Drew was elected a Fellow of the Geological Society in 1858, and of the Royal Geographical Society in 1872 .

\section{MISOEIIAINEOUS.}

\section{William Syith, L.L.D., "The Father of Exglish Geology."}

Prof. Judd has called attention to an error, often copied from "The Life of William Smith," by his nephew, the late Professor John Phillips, F.R.S., of Oxford, in which it is stated that "his bust, surmounting the tablet to his memory, is in the beautiful antique church of All Saints, at Northampton, where his remains lie buried" (see Geoc. Mag. for Feb. 1892, p. 90̃). William Smith lies buried a few feet from the west tower of the fine old Norman chureh of SAIst Peter's at North. ampton. The bust is placed within the ehurch, against the west wall of the nave, south of the grand Norman arch over the entrance to the tower. It stands on a marble pedestal inscribed:-

"To honour the name of William Smith, LL.D. This monument is erected by Friends and Fellow-labourers in the field of British Geology. Born 23rd March, 1769, at Churchill in Oxfordshire, and trained to the Profession of a Civil Engineer and Mineral Surreyor, He began, in 1791, to survey collieries and plan canals ir the vicinity of Bath, and having observed that several strata of that District were characterized by peculiar groups of organic remains, he adopted this fact as a principle of comparison, and was by it enabled to identify the strata in distant parts of this Island, To construct sections, and to complete and publish in 1815 a Geological Map of England and Wales. By thus devoting, during his whole life, all the power of an observing mind to the advancement of one Branch of Science, he gained the title of the 'Father of English Geology.' While on his way to a Meeting of the British Association for the Advancement of Science at Birmingham, he died in this town, at the house of his friend George Baker, the historian of Northamptonshire, 28th August, 1839.2

1 From Proc. Roy. Geographical Soçiety, vol, xiv. No. 1, January, 1892, p. 5254, by W. T. Blanford, LL.D., F.R.S.

${ }_{2}$ I am indebted to the Rev. E. N. Tom, M.A., Rector of St. Peter's, Northampton, for the above transiript. There is no sculptor's name on the bust. $-\mathrm{H}$. W. 